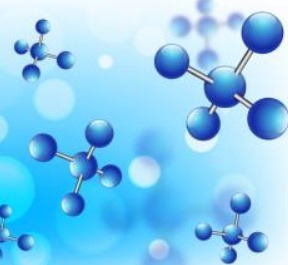

Research and Practice

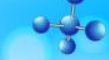

Article

\title{
Differences of Zinc and Copper Levels in Placenta Blood Normal Neonates and Intrauterine Growth Restriction
}

\author{
Melda Amalia ${ }^{1}$, Yusrawati $^{2}$, Rauza Sukma Rita $^{3}$ \\ ${ }^{1}$ Prodi Magister S2 Ilmu Kebidanan Fakultas Kedokteran Universitas Andalas Padang \\ ${ }^{2}$ Obstetry Ginekologi Fakultas Kedokteran Unand \\ ${ }^{3}$ Sub Bagian Biokimia FK Unand
}

SUBMISSION TRACK

KEYWORDS

Write, no more, than, five, keywords

CORRESPONDENCE

Phone: 081374619874

E-mail: mandria_bdr@yahoo.com

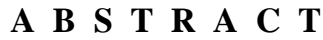

Zink and copper are the micronutrients which play a role in the growth and development of fetal and infant. Its deficiency in pregnant women shall give a birth the restriction fetal growth ${ }^{16,11}$. This research is proposed to distinguish zinc and copper levels in normal neonates and those restriction fetal growth.

The research was conducted with a comparative cross sectional analysis, experienced by three hospitals those are TK III Reksodiwirjo Hospital, Dr. Rasidin Hospital, and Bayangkara Hospital in the city of Padang. It also conducted in the SMAK Padang Chemistry Laboratory in November 2016 - January 2018. The research sample was taken from newborn blood centers for 60 respondents by consecutive sampling. Zinc and copper levels were examined by Atomic Absorption Spectrophotometry (AAS). Hypothesis testing was done by unpaired $t$ testing.

The results showed the average zinc level in restriction fetal growth group was $89.34 \pm 31.53 \mu \mathrm{g} / \mathrm{dL}$ and normal neonates were $122.703 \pm 39.3 \mu \mathrm{g} / \mathrm{dL}$ with $\mathrm{p}=$ 0.01 . The mean copper content in the restriction fetal growth group was $0.5142 \pm 0.15 \mu \mathrm{g} / \mathrm{dL}$ and the normal neonate was $0.6892 \pm 0.17 \mu \mathrm{g} / \mathrm{dL}$ with $\mathrm{p}<0.01$

The conclusion of this research is zinc and copper levels in normal neonates were significantly higher than neonatal zinc and copper levels restriction fetal growth.

\section{INTRODUCTION}

Infant Mortality Rate (IMR) is one indicator that shows the success of health development programs, especially maternal and child health. According to the target of Sustainable Development Goals (SDGs) in 2030 that is to end infant and under-five mortality, at least reduce the neonatal mortality rate by at least 12 per 1000 live births and under-five mortality rate per 1000 live births. In addition, ending all forms of malnutrition in children under five, nutrition of young women, pregnant and lactating women and the elderly are also included in the SDGs 2030 target. Based on UNICEF data in 2015 the $45 \%$ neonatal mortality rate was caused by malnutrition and $16 \%$ caused 
by premature. Bad nutrition does not only occur in developing countries, developed countries (industries) also experience malnutrition. The causes of malnutrition are macronutrient deficiency and micronutrient deficiency ${ }^{6,8,19}$.

Micronutrient deficiency is one of the main problems that occur in developing countries, especially in infants and pregnant women. Micronutrients are needed by babies to maintain normal growth and development. Common deficiencies include iron deficiency, calcium, vitamin D, Vitamin A, zinc and copper. Micronutrient deficiencies such as zinc and copper can cause reproductive health disorders such as infertility, congenital anomalies, pregnancy hypertension, placental abruption, premature rupture of membranes (KPD), low birth weight births ${ }^{16,10}$.

The results of Zadrozna et al. (2009) research in Poland found a decrease in zinc levels by $37 \%$ and copper by $27 \%$ in neonates born with restriction fetal growth, besides that there was a strong correlation between zinc and copper levels on enzyme activity. superoxide and baby's weight, especially in infants with restriction fetal growth. The results of Maamouri et al. (2011) research in Iran, Bermudez et al. (2015) in Spain, Khoushabi et al. (2016) in Iran there is also a significant relationship between zinc and copper levels of the weight and length of newborns. Low zinc and copper levels during pregnancy can cause fetal growth and development to be disrupted during pregnancy. However, these results are different from those of Wici Septiani, Nur Indrawati Lipoeto and Joserizal Seruji (2016) regarding the relationship of folic acid intake, zinc, and vitamin $\mathrm{A}$ in the third trimester pregnant women on birth weight in Padang Pariaman District showed no association between folic acid intake, zinc and vitamin A pregnant women in the third trimester of birth weight. Based on the description above, the purpose of this research was to determine differences in neonatal zinc and copper levels between normal neonates and restriction fetal growth.

\section{METHODS}

A cross sectional comparative research design, the research was conducted in November 2016 - January 2018. The sample of this research was a center which was cut toward 60 newborns taken by consecutive sampling. The sample in this research is part of the population that fulfills the criteria for inclusion and exclusion. Inclusion criteria included infants with birth restriction fetal growth, normal birth, mothers with singleton pregnancies, live fetuses and mothers who were willing to become research subjects. Exclusion criteria were twin pregnancies seen from Ultrsonography (USG) and palpation; Having congenital abnormalities, the mother suffers from systemic infections, diabetes mellitus, heart disease, hypertension, and kidney disorders; Mother with obesity, Chronic Energy Deficiency (KEK); Mother is active smoker and consumes active alcohol.

The sample was divided into two groups, namely the group diagnosed with fetal growth and the normal group of infants. Diagnosis determination is carried out according to the results of the quasier intrauterine growth curve. Samples are taken after the baby is born and before the placenta is born ( \pm 5 minutes). Blood is taken as much as $2.5 \mathrm{cc}$, then put into a vacuum container. Blood samples were taken to the Biomedical Laboratory of the Medical Faculty in Andalas University, Padang to be centrifuged at a speed of $3000 \mathrm{rpm}$ for 15 minutes until serum was formed over the clot. Furthermore, serum is stored at -200C until the number of samples is fulfilled. After the sample is met, then zinc and copper levels are examined. Examination of zinc and copper levels was carried out in the Middle School Laboratory of Padang Chemical Analysis.

Zinc and copper levels were examined by Atomic Absorption Spectrophotometry (AAS). Data normality test with KolmogrovSmirnov test then after that followed by unpaired t test. 


\section{RESULT}

The subjects of this research consisted of 60 neonates who were divided into two, namely 30 normal neonates and 30 neonates with fetal growth restriction in 3 hospitals namely TK III Reksodiwirjo hospital, Dr. Rasidin, Bayangkara Hospital in the city of Padang.

\section{Characteristics of Subject}

Data normality test was carried out before testing differences in mean age, hemoglobin, BMI, blood sugar and leukocytes of normal neonatal mothers with restriction fetal growth. Data normality test was carried out using the KolmogorovSmirnov test because the sample consisted of $\geq 50$ samples. The results of the normality test showed that 3 data were normally distributed with $p>0.05$ and 2 data were not normally distributed. Data that is not normally distributed are formatted with a $\log$ 10 value so that the value of $p>0.05$ is obtained.

Table 1.1 Subject Characteristics (age, body mass index (BMI), hemoglobin $(\mathrm{Hb})$ between normal neonates and restriction fetal growth

\begin{tabular}{|c|c|c|c|c|}
\hline \multirow[b]{2}{*}{$\begin{array}{l}\text { Characteristics } \\
\text { of Respondents }\end{array}$} & \multicolumn{2}{|c|}{ Groups } & \multirow[t]{2}{*}{ Sig. ${ }^{8}$} & \multirow[t]{2}{*}{$\mathbf{P}^{8}$} \\
\hline & $\begin{array}{l}\text { Normal } \\
\text { Neonates } \\
n=30 \\
\text { Mean } \pm \text { SD }\end{array}$ & $\begin{array}{l}\text { Fetal Growth } \\
\text { Fetus Is } \\
\text { Obstructed } \\
\text { n=30 } \\
\text { Mean } \pm \text { SD }\end{array}$ & & \\
\hline Ages (year) & $28,13 \pm 4,69$ & $28,53 \pm 5,9$ & 0,200 & 0,756 \\
\hline $\begin{array}{l}\text { Hemoglobin } \\
(\mathrm{g} / \mathrm{dl})\end{array}$ & $10,55 \pm 1,20$ & $10,55 \pm 1,26$ & 0,200 & 0,408 \\
\hline IMT & $22,53 \pm 1,88$ & $22,14 \pm 1,69$ & 0,200 & 0,967 \\
\hline Log 10 Glucose & $93,20 \pm 10,13$ & $94,73 \pm 14,41$ & 0,055 & 0,677 \\
\hline $\begin{array}{ll}\text { Log } & 10 \\
\text { Leukocytes } & \end{array}$ & $9996,67 \pm 2319,21$ & $10135 \pm 2089,29$ & 0,200 & 0,774 \\
\hline
\end{tabular}

Table 1.2 Characteristics of Subjects (Arm Circumference, Body Length, Head Circumference, Placental Weight, Parity)

\begin{tabular}{|c|c|c|c|}
\hline \multirow[b]{2}{*}{$\begin{array}{l}\text { Characteristics } \\
\text { of Respondents }\end{array}$} & \multicolumn{2}{|c|}{ Groups } & \multirow[t]{2}{*}{ Sig.p } \\
\hline & $\begin{array}{c}\text { Normal } \\
\text { Neonates } \\
\mathbf{n}=\mathbf{3 0} \\
\text { Median (max- } \\
\text { min) }\end{array}$ & $\begin{array}{l}\text { Fetal Growth } \\
\text { Fetus Is } \\
\text { Obstructed } \\
\text { n=30 } \\
\text { Median (max- } \\
\text { min) }\end{array}$ & \\
\hline LILA & $25(27-23,3)$ & $24(29-23,5)$ & 0,00 \\
\hline $\mathrm{PB}(\mathrm{cm})$ & $48(51-39)$ & $44,5(48-31)$ & 0,07 \\
\hline LK (cm) & $33,50(36-32)$ & $32(33-30)$ & 0,00 \\
\hline $\begin{array}{l}\text { Mass } \\
\text { Placenta(gram) }\end{array}$ & $512,5(587-500)$ & $479,5(500-430)$ & 0,00 \\
\hline $\begin{array}{l}\text { Sig. }{ }^{p} \text { Normality } \\
\mathrm{p}^{\mathrm{p}} \text { mann whitne }\end{array}$ & & & \\
\hline
\end{tabular}

2. Differences in zinc and copper levels in normal neonates and fetal growth are restriction

Table 2.1 Differences in zinc levels in normal neonates and restriction fetal growth

\begin{tabular}{|c|c|c|c|}
\hline \multirow[b]{2}{*}{ Variable } & \multicolumn{2}{|c|}{ Group } & \multirow[b]{2}{*}{$\mathbf{P}$} \\
\hline & $\begin{array}{c}\text { Normal } \\
\text { Neonates } \\
\mathbf{n}=30 \\
\text { Mean } \pm \\
\text { SD }\end{array}$ & $\begin{array}{c}\text { Fetal Growth } \\
\text { Fetus Is } \\
\text { Obstructed } \\
\mathbf{n}=30 \\
\text { Mean } \pm \text { SD } \\
\end{array}$ & \\
\hline $\begin{array}{c}\text { Zink Level } \\
(\mu \mathrm{g} / \mathrm{dL})\end{array}$ & $\begin{array}{c}122,70 \pm \\
39,3\end{array}$ & $89,34 \pm 31,53$ & 0,01 \\
\hline
\end{tabular}

Table 2.2 Differences in the levels of copper in normal neonates and fetal growth are restriction

\begin{tabular}{|c|c|c|c|}
\hline \multirow[b]{2}{*}{ Variable } & \multicolumn{2}{|c|}{ Group } & \multirow[b]{2}{*}{$\mathbf{P}$} \\
\hline & $\begin{array}{c}\text { Normal } \\
\text { Neonates } \\
\text { n=30 } \\
\text { Mean } \pm \\
\text { SD }\end{array}$ & $\begin{array}{c}\text { Fetal Growth } \\
\text { Fetus Is } \\
\text { Obstructed } \\
\text { n=30 } \\
\text { Mean } \pm \text { SD }\end{array}$ & \\
\hline $\begin{array}{c}\text { Copper } \\
\text { Level } \\
(\mu \mathrm{g} / \mathrm{dL})\end{array}$ & $0,69 \pm 0,17$ & $0,51 \pm 0,15$ & 0,001 \\
\hline
\end{tabular}

$\mathrm{SD}=$ Standard of deviation

Unpaired T test

\section{DISCUSSION}

\subsection{Subjective Characteristics}

The results of this research can be seen subjective groups that influence the incidence of restriction fetal growth, namely. infant length, head circumference and placental weight with $p=0.00(p<0.05)$ and for criteria for age, BMI, hemoglobin, 10 blood sugar log, log 10 Leukocytes, LiLa, and Parity with $\mathrm{p}$ values> $0.005(0,756$; $0,408 ; 0,967 ; 0,677 ; 0,774 ; 0,06 ; 0,771)$. Based on these results it can be concluded that the length of the baby, head circumference and weight of the placenta affect the incidence of fetal growth. On the 0,8fontrary, age, BMI, hemoglobin, blood 0, squgar, leukocytes, arm circumference (LILA) and parity did not affect the occurrence of restriction fetal growth. 


\subsection{Differences in zinc and copper levels in normal neonates and fetal growth are restriction}

1.2.1 Differences in normal and neonatal neonatal zinc levels $(\mathrm{Zn})$ are restriction fetal growth

The mean zinc levels in fetal growth of fetus were lowered lower than the mean zinc levels in normal neonatal mothers with $\mathrm{p}=$ 0.01 ( $\mathrm{p}<0.05)$.

Srivastava et.al (2002) found similar results, where the mean zinc levels were lower in low birth weight neonates $(7.86 \pm$ $8.16 \mu \mathrm{g} / \mathrm{mL}$ ) compared to normal neonates $(9.46 \pm 8.35 \mu \mathrm{g} / \mathrm{mL})$. This result is also the same as the research of Tsuzuki, et.al, (2013) and the research of Elizabeth, et.al (2008) which states that zinc levels in preterm neonates are lower than normal neonates. The results of this research were similarly obtained by the studies of Seriana, Yusrwati, \& Lubis (2015) there was a significant relationship between zinc levels of aterm pregnant women with birth weight with $\mathrm{p}=$ 0.152 ( $p>0.05)$.

Zinc is one of the trace elements needed by the fetus for fetal growth and development even in small amounts. Zinc is also needed in physiological functions, including immune function, antioxidants, growth and reproduction. Therefore the fetus's need for zinc is still dependent on maternal zinc levels ${ }^{12}$.

Obstructed fetal growth is a failure to achieve the proper growth. Obstructed fetal growth can cause fetuses and neonates at risk of perinatal death or disability, and have an effect on childhood by increasing the risk of hypertension, cardiovascular disorders and kidney disease. According to Sharma et al (2016) factors that cause fetal growth are restriction, namely maternal, fetal and placental factors.

Placental dysfunction is one of the causes of delayed fetal growth. Abnormalities of placental structure and function can affect the outcome of pregnancy (fetus). Normally endovascular trophoblasts will join the maternal spiral ateriol and replace smooth muscle into vascular which enhances the intervillus space. The first semester of pregnancy the development of the placenta is filled with low oxygen with a pressure of $<15 \mathrm{mmHg}$ so that the placental villi develop. Placental villi are fetal blood vessels that drain all fetal needs between mother and fetus. Placental villous development in normal conditions causes transportation of fetal needs to be fulfilled including the need for zinc (Scifres \& Nelson, 2009). This is consistent with the results of research with proven levels of zinc higher in normal neonates than in neonates restriction fetal growth.

$3 \%$ of cases of restriction fetal growth are due to placental insufficiency. Placental insufficiency causes defects in placental circulation and transport affects nutrient transport, especially zinc hygiene, which causes restriction fetal growth ${ }^{2}$. This is seen in the statistical results, with $\mathrm{p}=0,000$ indicating placenta is one of the factors that causes the transportation of nutrients such as zinc and copper needed by the fetus to be disturbed.

Maternal factors also play an important role in preventing fetal growth is restriction. In this research, zinc status was seen from zinc levels in maternal age, BMI> 18.5 and $<30$, Hemoglobin and blood sugar, single and living fetuses, leukocyte levels $<16,000$ $\mathrm{mm} 3$, mothers did not experience diabetes mellitus, heart disease, hypertension, kidney disorders, neonates do not experience congenital abnormalities and mothers who are not smokers and active alcohol. The results of the research of maternal factors have no effect on neonates restriction fetal growth. This result is based on statistics shown by the value of $p>0.05$.

Maternal nutritional status during pregnancy is one of the important factors for fetal growth and development ${ }^{1}$. About $82 \%$ of pregnant women experience zinc deficiency (Chafee \& King, 2012). The need for zinc in pregnant women will continue to increase along with fetal growth. In line with the increasing need for zinc causes adjustment of zinc absorption and excretion 
13. According to Gernand et al. (2016) zinc requirements will contribute to placental development and indirectly related to pregnancy outcome.

Vascular vascularization of the placental tissue requires the invasion of external trophoblast cells from the embryo into the maternal decidua, this process causes oxidative stress so that it requires antioxidant nutrients. The placenta requires antioxidant enzymes from micronutrients such as glutathione peroxidase (selenium) and superoxide dismutases (copper, zinc and manganese) which play an important role in protecting the fetus and placenta due to oxidative stress of the maternal spiral artery joining the placental villi to begin fetal circulation to the mother. Insufficient antioxidant activity will cause a decrease in placental vascularization thus limiting blood flow which results in hypoxia, ischemia, preeclampsia and impaired fetal growth.

\subsection{Differences in normal and neonatal neonatal copper levels are restriction fetal growth}

In this research the average copper content in the mother of the fetus of fetal growth was lower $(0.5142 \pm 0.15 \mu \mathrm{g} / \mathrm{dL})$ compared to the mean zinc levels in normal neonatal mothers $(0.6892 \pm 0.17 \mu \mathrm{g} / \mathrm{dL})$. The results of unpaired t test showed that there were differences in copper levels between normal neonates and neonatal growth fetuses which were restriction by $\mathrm{p}=$ $0.00(\mathrm{p}<0.05)$.

The results of Tsuzuki et.al's research (2013) stated that copper levels in normal neonates were higher than those in fetal growth restriction ie, $36.4 \pm 11.9 \mu \mathrm{g} / \mathrm{dL}$, and $28.3 \pm 10 \mu \mathrm{g} / \mathrm{dL}$. This result is also the same as that of Abbas et al (2014), and Maamouri, et al., (2011) which states that copper levels in normal neonates are higher than low birth neonates. Based on statistical results there is a relationship between copper levels of normal neonates and neonatal fetal growth restriction by $\mathrm{p}=0.001(\mathrm{p}<0.05)$.

Copper is a trace element that plays an important role in biological functions, namely as an enzymatic cofactor. Copper minerals are also needed to build body tissue. In addition, the content of copper has a function in metabolism as a component of enzymes, cofactors, and proteins in the body. Indirectly copper functions in the body's immune, nervous and cardiac systems, bone health, iron metabolism, red blood cell formation, mitochondrial regulation and gene expression. In addition copper mineral deficiency can interfere with growth.

Copper with Zinc functions in the antioxidant enzyme, superoxide dismutases, is able to overcome oxidative stress or radical oxygen. This radical oxygen is one of the factors that can trigger premature birth. Research shows the presence of low copper levels in the neontus with fetal growth restriction compared to normal neonates.

\section{CONCLUSION}

There are differences in zinc and copper levels between normal and neonatal neonates restriction fetal growth, where zinc levels in normal neonates are higher at $122.70(\mu \mathrm{g} /$ dL) than neonates restriction fetal growth of $89.34(\mu \mathrm{g} / \mathrm{dL})$ and copper log content in normal neonates it is higher that is $0.69(\mu \mathrm{g} /$ $\mathrm{dL}$ ) than the neonate restriction fetal growth of $0.51(\mu \mathrm{g} / \mathrm{dL})$. 


\section{REFERENCE}

1. Almatsier, A. (2009). Prinsip Dasar Ilmu Gizi. Jakarta: PT Gramedia Pustaka Utama.

2. Anju, S., \& Berghella, V. (2013). Intrauterine Growth Restriction (IUGR): Etiology and Diagnosis. Springer, 102-111.

3. Bermudez, L., Vicent, C. G., Lopez, J., Torro, M. I., \& Luber, E. (2015). Assesment of Ten Trace Elements in Umbilical Cord Blood and Maternal Blood: Association with Birth Weight. Journal of Translational Medicine, 13:291.

4. Elizabeth, K., Krishnan, V., \& Vijayakumar, T. (2008). Umbilical Cord Blood Nutrients in Low Birth Weight Babies in Relation to Birth Weight \& Gestational Age. Indian J Med Res, 128-133.

5. Gernand, A. D., Schulze, K. J., Stewar, C. P., West Jr., K. P., \& Christian , P. (2016). Micronutrient deficiencies in pregnancy worldwide: health effects and prevention. Nat Rev Endocrinol, 274-289.

6. Gibney, M. J. (2009). Gizi Kesehatan Masyarakat. Jakarta: EGC.

7. Kemenkes RI (2015). Kesehatan Dalam Kerangka Sustainable Development Goals (SDGs). Jakarta : Kementrian Kesehatan RI.

8. Kemenkes RI. (2015). Situasi Gizi. Jakarta: Infodatin.

9. Khoushabi, F., Shadan, M. R., \& Sharifi-Rad, J. (2016). Determination of Maternal Serum Zinc, Iron, Calcium and Magnesium During Pregnancy in Pregnant Women and Umbilical Cord Blood and Their Association with Outcome of Pregnancy. Mater Sociomed, 104-107.

10. Linder, M. C. (2010). Biokimia Nutrisi dan Metabolisme (Aminuddin Parakkasi ed.). Jakarta: Universitas Indonesia (UI-Press).

11. Maamouri, G., Boskabadi, H., Noria, M., Ayatollahi, H., Ghayour-Mobarhan, M., Heshmati, A., et al. (2011). Maternal and Neonatal Zinc and Copper Levels and Birth Weight. Iranian Journal of Neonatology, 26-31.

12. Ozdemir, U., Gulturk, S., Guvenal, T., Imir, G., \& Erselcan, T. (2007). Correlation between birth weight, leptin, zinc and copper levels in maternal and cord blood. J.Physiol Biochem, 63-71.

13. Ross, A. C., Caballero, B., Cousins, J. R., Tucker, K. L., \& Ziegler, T. R. (2014). Modern Nutrition in Health and Disease 11th edition. Philadelphia: Lippincott Williams \& Wilkins. 
14. Seriana, I., Yusrwati, \& Lubis, G. (2015). Hubungan Kadar Zink (Zn) Serum Ibu Hamil Aterm Dengan Beratbadan Lahir Di Rsup Dr. M. Djamil Padang. Jurnal Kesehatan Ilmiah Nasuwakes Vol. 8, 8-14.

15. Sharma, D., Shastri, S., \& Sharma, P. (2016). Intrauterine Growth Restriction: Antenatal and Postnatal Aspects. Libertas Academica, 67.

16. Soetan, K. O., Olaiya, C. O., \& Oyewole, O. E. (2010). The Importance of Mineral Elements for Human, Domestic Animals, and Plants: Review. African Journal of Food Science, 200-222.

17. Srivastava, S., Mehrotra, P., Srivastava, S., \& Siddiqui, M. (2002). Some Essential Elements in Maternal and Cord Blood in Relation to Birth Weight and Gestational Age of the Baby. Biological Trace Element Research, 97-106.

18. Tsuzuki, S., Morimoto, N., Hosokawa, S., \& Matsushita, T. (2013). Associations of Maternal and Neonatal Serum Trace Element Concentrations with Neonatal Birth Weighht. PLOS ONE, 1-5.

19. UNICEF. (2015). Causes of Deaths among Children Under 5 years. New York: The United Nations Children's Fund.

20. Zadrozna, M., Gawlik, M., Nowak, B., Marcinekc, A., Mrowiec, H., Walas, S., et al. (2009). Antioxidants Activities and Concentration of Selenium, Zinc and Copperin. Journal of Trace Elements in Medicine and Biology, 144-149.

21. Abbas, R. M., Hamdan, Z., Elhassan, m., Hamdan, S. Z., Ali, N. I., \& Adam, I. (2014). Zinc and Copper levels in low birth weight deliveries in Medani Hospital, Sudan. BMC Research Note, 1-5. 
